\title{
Waterbird-Mediated Dispersal and Freshwater Biodiversity: General Insights From Bryozoans
}

\author{
Beth Okamura *, Hanna Hartikainen ${ }^{\dagger}$ and Jahcub Trew $^{\dagger}$ \\ Department of Life Sciences, Natural History Museum, London, United Kingdom
}

\section{OPEN ACCESS}

Edited by:

Casper H. A. Van Leeuwen

Netherlands Institute of Ecology

(NIOO-KNAW), Netherlands

Reviewed by:

Ganesh K. Jaganathan, University of Shanghai for Science and

Technology, China

Ádám Lovas-Kiss,

Institute of Ecology Research Center

(MTA), Hungary

*Correspondence:

Beth Okamura

b.okamura@nhm.ac.uk

${ }^{\dagger}$ Present Address:

Hanna Hartikainen,

Eawag, Swiss Federal Institute of

Aquatic Science and Technology,

Dübendorf, Switzerland;

ETH Zürich,

Institute of Integrative Biology (IBZ),

Zürich, Switzerland

Jahcub Trew,

Biosciences, College of Life and Environmental Sciences, University of

Exeter, Exeter, United Kingdom

Specialty section:

This article was submitted to Biogeography and Macroecology,

a section of the journal

Frontiers in Ecology and Evolution

Received: 28 September 2018

Accepted: 28 January 2019

Published: 15 February 2019

Citation:

Okamura B, Hartikainen $\mathrm{H}$ and Trew J (2019) Waterbird-Mediated Dispersal and Freshwater Biodiversity: General

Insights From Bryozoans.

Front. Ecol. Evol. 7:29.

doi: 10.3389/fevo.2019.00029
Freshwater environments are fragmented and heterogeneous in space and time. Long term persistence thus necessitates at least occasional dispersal of aquatic organisms to locate suitable habitats. However, the insubstantial movements of many require zoochory-hitchhiking a ride with more mobile animals. We review evidence for waterbird-mediated zoochory of freshwater bryozoans, a group that provides an excellent model for addressing this issue. The feasibility of long distance transport by waterbirds of bryozoan propagules (statoblasts) is evaluated in relation to statoblast resistance to extreme conditions and waterbird gut retention times, flight durations and distances. We highlight genetic evidence for colonization following waterbird-mediated transport. The consequences of zoochory for biodiversity are manifold. Taxa that release statoblasts show lower levels of genetic differentiation, genetic divergence and haplotype diversity than those whose statoblasts are retained in situ (hence less available for zoochory). Zoochory may also disseminate pathogens and parasites when infected host stages are transported. Such co-dispersal may explain some disease distributions and is supported by viability of infected statoblasts. Zoochory can also be expected to influence local and regional population and community dynamics, food web structure and stability, and organismal distributions, and abundances. Finally, zoochory may influence host-parasite coevolution and disease dynamics across the landscape with the benefits to parasites depending on their life history (e.g., simple vs. complex life cycles, generalists vs. specialists). Our synthesis highlights the complex ecological and evolutionary impacts of zoochory of freshwater organisms and raises questions for future research.

Keywords: waterbirds, migration, statoblasts, dispersal potential, evolutionary consequences, genetic flow, divergence, parasite co-dispersal

\section{INTRODUCTION}

Freshwater environments are patchy in space and time and surrounded by an inhospitable landscape. Such patchiness can challenge aquatic organisms when their habitats deteriorate. Larger mobile animals may actively escape such conditions, colonizing distant more suitable sites by flying, swimming walking, hopping, or crawling. Many freshwater invertebrates, however, are incapable of undertaking sufficiently large-scale movements to ensure successful dispersal. Instead they rely on animals with shared habitats to transport resistant stages. Such passive dispersal (Bilton et al., 2001) to new sites mitigates against local extinction and entails potential impacts on biodiversity. Freshwater bryozoans have proven to be an excellent model system to reveal how aquatic 
invertebrates depend on transport by mobile animals (zoochory) to ensure their long term persistence in dynamic and patchy freshwater environments (Okamura and Freeland, 2002) and the consequences of such dispersal for biodiversity and evolution.

Here we review evidence for zoochory by waterbirds and evaluate the feasibility of occasional long distance transport by migratory birds. We examine how rates of zoochory may vary amongst bryozoan taxa and associated clade-dependent patterns of diversification. Finally, we consider the consequences of zoochory for community development and biodiversity revealed by the potential for co-dispersal of infectious agents in dormant dispersive propagules. The introduction of parasites via zoochory of such infected propagules could impact multiple host populations, food webs and metacommunity dynamics across the landscape. Our collective evidence simultaneously illustrates the importance of waterbird-mediated zoochory for ecological and evolutionary processes in inland waters and raises many general questions for future research.

\section{THE LIFE HISTORY OF FRESHWATER BRYOZOANS}

Freshwater bryozoans (Phylum Bryozoa: Class Phylactolaemata) comprise a relatively small group of exclusively freshwater taxa, with $<100$ described species (Massard and Geimer, 2008). During favorable conditions, bryozoans grow as colonies of physiologically-connected individual modules called zooids. Although not widely recognized, colonies are commonly found on macrophytes, submerged branches and tree roots, rocks, and man-made surfaces such as piers, buoys, floats, plastic, and boat hulls in both lotic and lentic environments. Each zooid possesses a tentacular crown (the lophophore) whose ciliary currents enable feeding on suspended particles. Budding of new zooids increases colony size and determines a range of colony morphologies (Figure 1A).

The life history of freshwater bryozoans entails extensive clonal reproduction in the form of colony growth, colony fragmentation or fission, and the production of specialized stages (statoblasts) that enable persistence during adverse conditions (Figure 1A). Statoblasts are asexual propagules with germinal tissue enclosed within protective chitinous valves. Low metabolism enables dormancy and survival during unfavorable times. When favorable conditions return statoblasts "hatch" and the first zooid of a new colony emerges from separated valves. Non-dormant statoblasts can contribute to overlapping generations within a single growing season (Brown, 1933; Wood and Okamura, 2005). Dormant statoblasts overwinter in temperate regions and may enable persistence during dry seasons in tropical environments (Wood, 2002).

Many statoblasts are buoyant and float after release from bryozoans. Some of these "floatoblasts" have projections such as hooks and spines (e.g., Cristatella mucedo; Figure 1A) enabling attachment to various surfaces, including feathers (Figure 1 in Bilton et al., 2001). Other statoblasts are not released, remaining quiescent in the previously favorable parental microhabitat ("sessoblasts" in Plumatella and "piptoblasts" in Fredericella; Figure 1A). Plumatella species produce both floatoblasts and sessoblasts-a dispersal polymorphism (Karlson, 1992).

Statoblasts production varies from $<1$ to up to 27 per zooid dependent on species (Bushnell, 1973; Wood, 1973; Karlson, 1992) and typically peaks at the end of the growing season (e.g., in late summer/early autumn in temperate regions). Brown (1933) estimated that some 80,000 statoblasts could be released from Plumatella repens colonies growing on an averagesized Potomageton natans plant. Collectively huge numbers of statoblasts can be produced within sites. For example, a 0.3$1.2 \mathrm{~m}$-wide shore drift of statoblasts extended for $0.8 \mathrm{~km}$ along a bay of Douglas Lake, Michigan (Brown, 1933). These various statoblast features support another critical function: dispersal amongst sites.

\section{WATERBIRD-MEDIATED STATOBLAST TRANSPORT: THE EVIDENCE}

Statoblasts are repeatedly documented in feces and digestive tracts or on external surfaces of waterbirds (Table 1). Their transport could be achieved externally (ectozoochory) if they are attached to feathers, reside in mud clinging to birds, or adhere by surface tension or electrostatic attraction. Alternatively statoblasts may be ingested and excreted by birds (endozoochory). The majority of birds providing evidence for statoblast transport are dabbling and diving ducks, but coots, plovers (killdeer), and piscivorous birds (cormorants and pelicans) are also implicated. Bird prey may be relevant as statoblasts are recorded as fish dietary items (e.g., Osburn, 1921; Dendy, 1963; Marković et al., 2009). This collective evidence suggests that a diversity of birds could mediate both local and long distance dispersal.

For effective dispersal statoblasts must survive adverse conditions during transit. Statoblasts can hatch following exposure to desiccating conditions, freezing temperatures, and repetitive freezing and thawing (Brown, 1933; Hengherr and Schill, 2011; Abd-Elfattah et al., 2017). A proportion is typically also viable after passing through the digestive tracts of salamanders, frogs, fish, turtles, and ducks (Brown, 1933; Charalambidou et al., 2003a; Green et al., 2008; Brochet et al., 2010; Abd-Elfattah et al., 2017; Van Leeuwen et al., 2017) although, if assessed, hatching is reduced relative to controls. Intact statoblasts of four Plumatella species have been observed in $7.9 \%$ of 228 lower digestive tracts (ceca and intestine, where little digestion occurs) of 10 waterbird species (Figuerola et al., 2004). Bird species with heavier (potentially more destructive) gizzards and shorter ceca had a lower incidence and abundance of statoblasts in the lower gut. These results suggest that statoblast dispersal is more likely in birds with lighter gizzards and that longer ceca will entail a longer passage time which, in turn, may favor long distance dispersal. There is limited evidence that endozoochory is more common than ectozoochory (but viability was not tested) and that some waterbird species are more important as vectors, however sample sizes were low and analyses based on pooling statoblasts and cladoceran ephippia 


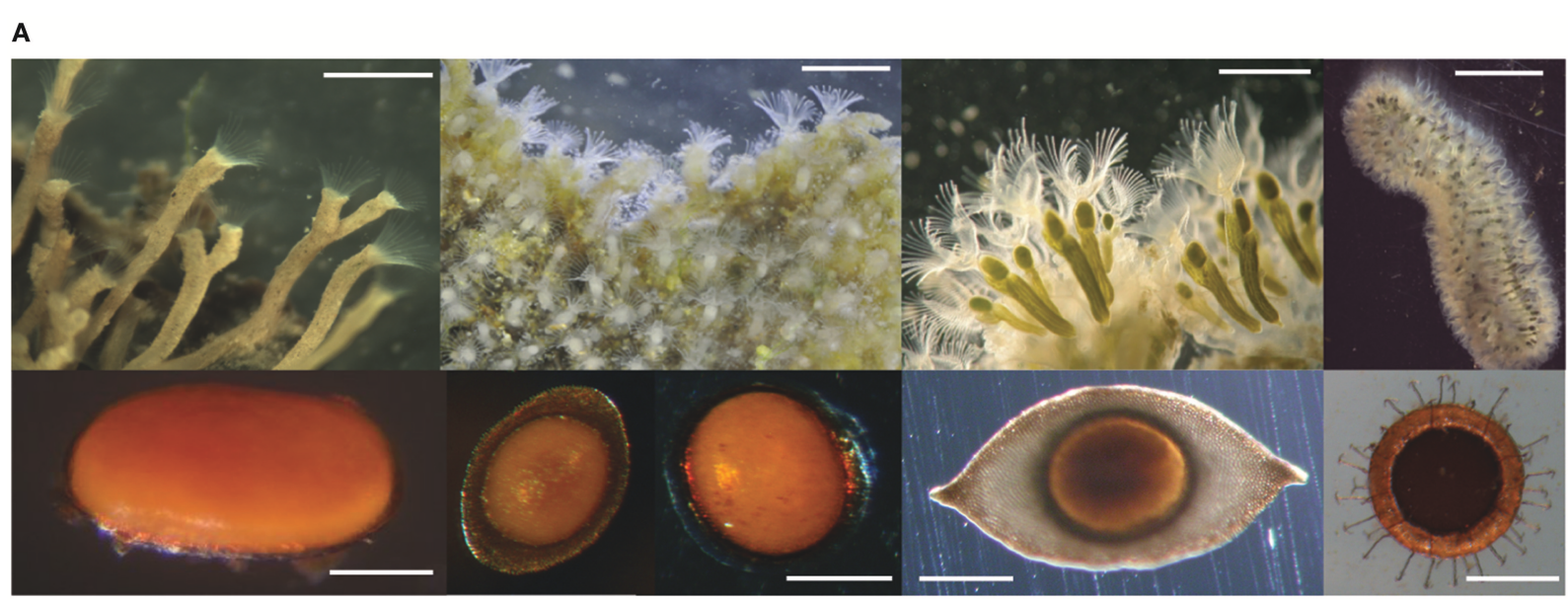

Statoblast dispersal potential

B

\begin{tabular}{|c|c|c|c|c|c|c|c|c|}
\hline & \multicolumn{4}{|c|}{ F. sultana } & \multicolumn{4}{|c|}{ C. mucedo } \\
\hline & Variance & $\begin{array}{l}\% \\
\text { total }\end{array}$ & $\begin{array}{l}\Phi- \\
\text { statistic }\end{array}$ & $P$ & Variance & $\begin{array}{l}\% \\
\text { total }\end{array}$ & $\begin{array}{l}\Phi- \\
\text { statistic }\end{array}$ & $P$ \\
\hline Among countries $\left(\mathrm{V}_{\mathrm{a}}\right)$ & 4.021 & 33.04 & $\begin{array}{l}\Phi_{\mathrm{CT}}= \\
0.331\end{array}$ & 0.000 & -0.011 & -1.15 & $\begin{array}{l}\Phi_{\mathrm{CT}}=- \\
0.012\end{array}$ & 0.255 \\
\hline $\begin{array}{l}\text { Among populations within } \\
\text { countries }\left(V_{b}\right)\end{array}$ & 4.212 & 34.61 & $\begin{array}{l}\Phi_{\mathrm{SC}}= \\
0.517\end{array}$ & 0.000 & 0.416 & 43.44 & $\begin{array}{l}\Phi_{S C}= \\
0.429\end{array}$ & 0.000 \\
\hline Within populations $\left(V_{c}\right)$ & 3.938 & 32.35 & $\begin{array}{l}\Phi_{\mathrm{ST}}= \\
0.676\end{array}$ & 0.000 & 0.553 & 57.71 & $\begin{array}{l}\Phi_{\mathrm{ST}}= \\
0.423\end{array}$ & 0.000 \\
\hline
\end{tabular}

C

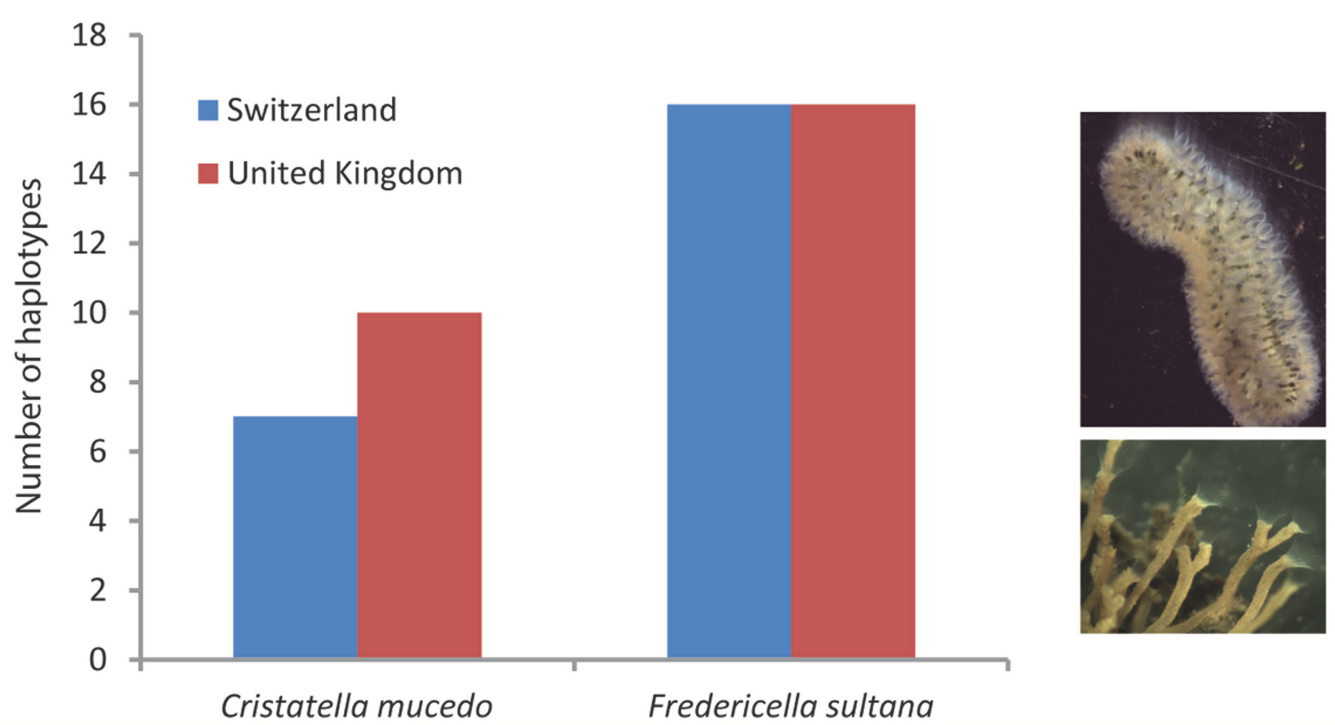

FIGURE 1 | Variation in dispersal potential (in terms of statoblast release, buoyancy, presence of hooks and spines) of freshwater bryozoans by waterbirds and its consequences. (A) Bryozoan colonies (upper panel from left to right: Fredericella sp.; Plumatella casmiana [image courtesy of T. Schwaha]; Lophopus crystallinus; Cristatella mucedo) and their associated statoblasts (lower panel from left to right: Fredericella piptoblast [image curtesy of T. Wood]; Plumatella floatoblast and sessoblast; Lophopus floatoblast; Cristatella floatoblast with hooks and spines) arranged according to increasing dispersal potential. Scale bars upper panel from left to right: $2 \mathrm{~mm}, 1.2 \mathrm{~mm}, 0.8 \mathrm{~mm}, 6 \mathrm{~mm}$. Scale bars lower panel from left to right: $0.3 \mathrm{~mm}, 0.4 \mathrm{~mm}, 0.4 \mathrm{~mm}, 0.5 \mathrm{~mm}$. (B) Analysis of molecular variance (AMOVA) of the mitochondrial DNA (nad4/H region) for Fredericella sultana and Cristatella mucedo in Switzerland and the UK (see Supplementary Tables 1, 2 for summary of population data). (C) Numbers of haplotypes of Fredericella sultana and Cristatella mucedo in Switzerland and the UK. Produced in Arlequin v3.5.1.2 (Excoffier and Lischer, 2010). 
TABLE 1 | Statoblasts present in feces or digestive tracts of waterbirds or collected externally from plumage or feet according to bird species and geographic region.

\begin{tabular}{|c|c|c|c|}
\hline Waterbird species & Geographic region & $\begin{array}{l}\text { Statoblast } \\
\text { collection }\end{array}$ & References \\
\hline Blue-winged teal (Anas discors) & Illinois & DT & Anderson, 1959 \\
\hline American pintail (Anas acuta) & Illinois, USA & DT & Anderson, 1959 \\
\hline Green-winged teal (Anas carolinensis) & Illinois, USA & DT & Anderson, 1959 \\
\hline American wigeon (Baldpate) (Mareca americana) & Illinois, USA & DT & Anderson, 1959 \\
\hline Lesser scaup (Aythya affinis) & Illinois, USA & DT & Anderson, 1959 \\
\hline Ring-necked duck (Aythya collaris) & Illinois, USA & DT & Anderson, 1959 \\
\hline Redhead (Aythya americana) & Illinois, USA & DT & Anderson, 1959 \\
\hline Shoveler (Spatula clypeata) & Illinois, USA & DT & Anderson, 1959 \\
\hline Eurasian teal (Anas crecca) & Southern France; Northeast France & $\mathrm{E}^{\mathrm{a}}, \mathrm{DT}^{\mathrm{a}}, \mathrm{DT}^{\mathrm{b}}$ & $\begin{array}{l}\text { Mouronval et al., } 2007^{\mathrm{b}} \text {; Brochet et al., } \\
2010^{\mathrm{a}}\end{array}$ \\
\hline Gray teal (Anas gracilis) & New South Wales, Australia & $\mathrm{F}$ & Green et al., 2008 \\
\hline Eurasian coot (Fulica atra) & $\begin{array}{l}\text { Australia }{ }^{\mathrm{a}} \text {, southern Spain }{ }^{\mathrm{b}} \text {; } \\
\text { Northeast France }^{\mathrm{c}}\end{array}$ & $\mathrm{F}^{\mathrm{a}}, \mathrm{DT}^{\mathrm{b}}, \mathrm{DT}^{\mathrm{c}}$ & $\begin{array}{l}\text { Figuerola et al., 2004 }{ }^{\mathrm{b}} \text {; Mouronval et al., } \\
2007^{\mathrm{c}} \text {; Green et al., } 2008^{\mathrm{a}}\end{array}$ \\
\hline Black swan (Cygnus atratus) & New South Wales, Australia & $\mathrm{F}$ & Green et al., 2008 \\
\hline Australian pelican (Pelecanus conspicillatus) & New South Wales, Australia & $\mathrm{F}$ & Green et al., 2008 \\
\hline Northern shoveler (Anas clypeata) & Southern Spain & DT & Figuerola et al., 2004 \\
\hline Mallard (Anas platyrhynchos) & Southern Spain; Northeastern France & $\mathrm{DT}^{\mathrm{a}}, \mathrm{DT}^{\mathrm{b}}$ & $\begin{array}{l}\text { Figuerola et al., 2004 }{ }^{a} \text {; Mouronval et al., } \\
2007^{b}\end{array}$ \\
\hline Red-crested pochard (Netta rufina) & Southern Spain & DT & Figuerola et al., 2004 \\
\hline Greylag goose (Anser anser) & Southern Spain & DT & Figuerola et al., 2004 \\
\hline Ruddy duck (Oxyura jamaicensis) & Southern Spain & DT & Sánchez et al., 2000 \\
\hline $\begin{array}{l}\text { Ruddy duck (Oxyura jamaicensis)/White-headed duck } \\
\text { (O. leucocephala) hybrids }\end{array}$ & Southern Spain & DT & Sánchez et al., 2000 \\
\hline Marbled teal (Marmaronetta angustirostris) & Southern Spain & $\mathrm{F}, \mathrm{F}$ & $\begin{array}{l}\text { Green and Sánchez, 2003; Fuentes et al., } \\
2004\end{array}$ \\
\hline Great cormorant (Phalacrocorax carbo) & Southern Sweden; The Netherlands & $\mathrm{F}$ & Van Leeuwen et al., 2017 \\
\hline Widgeon (Anas penelope) & Northeast France & DT & Mouronval et al., 2007 \\
\hline Pochard (Aythya farina) & Northeast France & DT & Mouronval et al., 2007 \\
\hline Goldeneye (Bucephala clangula) & Northeast France & DT & Mouronval et al., 2007 \\
\hline Tufted duck (Aythya fuligula) & Northeast France & DT & Mouronval et al., 2007 \\
\hline Killdeer (Charadrius vociferous) & Oklahoma, USA & $\mathrm{F}$ & Green et al., 2013 \\
\hline Egyptian goose (Alopochen aegyptiaca) & Southern Africa & $\mathrm{F}, \mathrm{E}$ & Reynolds and Cumming, 2015 \\
\hline Spur-winged goose (Plectropterus gambensis) & Southern Africa & $\mathrm{F}$ & Reynolds and Cumming, 2015 \\
\hline Yellow-billed duck (Anas undulata) & Southern Africa & $\mathrm{F}$ & Reynolds and Cumming, 2015 \\
\hline White-faced duck (Dendrocygna viduata) & Southern Africa & $\mathrm{F}, \mathrm{E}$ & Reynolds and Cumming, 2015 \\
\hline Cape shoveler (Anas smithii) & Southern Africa & $\mathrm{F}$ & Reynolds and Cumming, 2015 \\
\hline Lesser-black backed gull (Larus fuscus) & Southern Africa & F, DT & Lovas-Kiss et al., 2018a \\
\hline
\end{tabular}

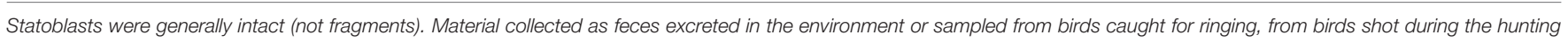

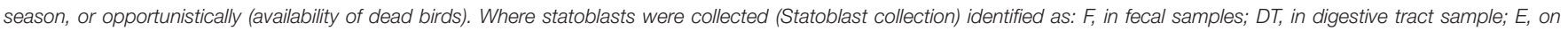
external surfaces (plumage or feet). Superscripts a-c link statoblast collection information with reference.

(Reynolds and Cumming, 2015). We must stress that zoochory is likely to be hazardous for statoblasts. Statoblast fragments in waterbird digestive tracts (e.g., Brown, 1933; Figuerola et al., 2004) suggest some break down and hatching of intact statoblasts retrieved from feces is reduced (unlike in some plant seeds; Jaganathan et al., 2016). Finally, zoochory is likely to be a relatively rare event, as most statoblasts will overwinter as uningested propagules.

Retention time in digestive tracts will critically determine potential dispersal distances and can vary with material ingested. Ten to 26 and greater $72 \mathrm{~h}$ have been estimated for mallard (Anas platyrhynchos) and blue-winged teal (Anas discors), respectively (Brown, 1933; Swanson and Bartonek, 1970; Agami and Waisel, 1986). Charalambidou et al. (2003a) found most Cristatella mucedo statoblasts were retained for $4 \mathrm{~h}$ but maximum retention times were 44 and $32 \mathrm{~h}$ in pintail (Anas acuta) and shoveler (Spatula clypeata), respectively. Although increased retention times may decrease viability as demonstrated for seeds (e.g., Charalambidou et al., 2003b), an early study concluded there was no relationship between length of time statoblasts were retained and subsequent hatching (Brown, 1933). Insights on waterbird flight speeds, distances traveled and measured 
retention times could enable occasional long distance dispersal of viable statoblasts. For example, a telemetry-based study found a maximum non-stop distance for pintail of 2,926 km over $38 \mathrm{~h}$ (using an average groundspeed of $77 \mathrm{~km} / \mathrm{h}$ for a flight from southern Oregon to the Kenai Peninsula, Alaska; Miller et al., 2005). Some mallards appear to fly non-stop from Arkansas to the Prairie Pothole Region in Canada (Krementz et al., 2011). We estimate this would also take around $38 \mathrm{~h}$ [considering a mean mallard airspeed of $70.9 \mathrm{~km} / \mathrm{h}$ (Pennycuick et al., 2013) and a linear distance of $2,675 \mathrm{~km}$ that modestly spans the migratory route]. These estimated non-stop flight times might enable dispersal over thousands of kilometers. However, many migrating waterbirds stop to feed. Average distances of such mallard migratory "legs" were 757, 446, and $664 \mathrm{~km}$ in 2004 , 2005, and 2006, respectively (Krementz et al., 2011), translating to some 11, 6, and $9 \mathrm{~h}$ of flight time (based on the above mean mallard airspeed). Pintail migratory legs times ranged from 1.64 to $5.12 \mathrm{~h}$ with associated travel distances of $99.8-393.3 \mathrm{~km}$ (Miller et al., 2005). Greater numbers of viable statoblast are likely to be introduced by such migratory legs.

The association of statoblasts with many waterbirds and the potential for transport given their resistant nature along with gut retention and bird migration times suggest that occasional long distance dispersal over hundreds to thousands of kilometers is feasible given the huge numbers of waterbirds undergoing such regular movements. In view of the disproportionate influence of such rare events on colonization, gene flow and population genetic structure, a recent operational definition for long distance dispersal involves crossing geographic boundaries of populations and contributing to effective gene flow (Jordano, 2017). While long distance dispersal is difficult to robustly characterize it is indeed specifically proposed to explain the broad geographic distributions of many freshwater bryozoans along waterbird migratory routes (Wood, 2002; Wood et al., 2006). The movements of more sedentary birds may contribute to short distance dispersal across local landscapes. Evidence that waterbird-mediated dispersal actually effects colonization comes in the form of genetic studies.

\section{GENETIC EVIDENCE THAT WATERBIRDS PROMOTE COLONIZATION}

The freshwater bryozoan, Cristatella mucedo (Figure 1A), has been especially valuable in demonstrating ongoing waterbirdmediated dispersal of freshwater organisms (De Meester et al., 2002; Okamura and Freeland, 2002). Freeland et al. (2000a) used microsatellites to characterize 14 populations collected along a major waterbird migratory route traversing northwestern Europe. Low levels of gene flow linked populations across the region and colonies with identical genotypes were collected from several sites, including two sites separated by $700 \mathrm{~km}$ of land and sea (in Sweden and The Netherlands). The latter result implies long distance transport of statoblasts by waterbirds. In addition, discriminant function analyses assigned $14 \%$ of individual colonies to populations other than those from which they were collected. The highest number of such cases was recorded for the Nationaal Park de Biesboschan important stopover site in The Netherlands for migratory waterfowl. In contrast, microsatellite analysis of 10 North American C. mucedo populations revealed highly differentiated populations with little evidence of recent gene flow across regions not linked by common waterbird migratory routes (Freeland et al., 2000b). Discriminant function analysis misassigned $8 \%$ of individual colonies to other populations and no clonal genotypes were shared between populations. More direct comparisons based on microsatellite markers common to both studies (Freeland et al., 2000c) revealed higher gene flow amongst European populations and misassignment of $32.5 \%$ of European colonies compared to $18.3 \%$ of colonies from North America. Finally, band recovery data (Figuerola et al., 2005) were shown to explain a significant proportion of variation in both genetic distance and gene flow amongst North American C. mucedo populations (and in two of three cladoceran species), even when controlling for geographic distance.

Collectively this body of evidence implies that waterbirds regularly disperse statoblasts and contribute to the metapopulation dynamics $C$. mucedo in both Europe and North America.

\section{DIFFERENTIAL DISPERSAL AND EVOLUTIONARY CONSEQUENCES}

The frequency and magnitude of waterbird-mediated dispersal and associated gene flow can be expected to influence genetic differentiation. Panmixia and low genetic differentiation between sites should result from high dispersal rates. As dispersal rates decrease, genetic differentiation will increase due to processes such as founder effects, genetic drift and natural selection. Genetic differentiation may ultimately lead to speciation if dispersal rates are very low and/or selection pressure is very high.

Accordingly, statoblast trait-linked influences on zoochory (e.g., buoyancy, hooks, and spines) appear to explain some patterns of genetic differentiation and divergence in freshwater bryozoans. Thus, molecular phylogenetic analysis has revealed contrasting patterns of divergence amongst bryozoan clades that vary in dispersal potential (Hartikainen et al., 2013). Fredericella exhibits a propensity for cryptic speciation and phylogeographical structure while Plumatella species exhibit low intraspecific divergence. Although sample sizes were small, these patterns are consistent with limited vs. widespread gene flow in fredericellids (which exclusively produce attached piptoblasts) and plumatellids (which produce both floatoblasts and sessoblasts), respectively (Figure 1A).

In a further relevant study we undertook matched sampling of F. sultana and C. mucedo populations in the UK and Switzerland (Supplementary Tables 1, 2). Contrasting patterns of genetic variation were in keeping with expected differences in dispersal potential. Analysis of molecular variance (AMOVA; Figure 1B) revealed greater genetic divergence between countries for F. sultana (which retains piptoblasts) compared to C. mucedo 
(which releases floatoblasts) (0.331 vs. -0.012 , respectively). The lack of between country genetic divergence for $C$. mucedo populations suggests that dispersal over hundreds of $\mathrm{km}$ is more frequent than local dispersal. Accordingly, there is relatively high within country genetic divergence $(0.429)$. These results implicate waterbirds as primary vehicles of $C$. mucedo dispersal. In addition, F. sultana exhibited a greater number of haplotypes than C. mucedo (Figure 1C). Analyses of data pooled across countries provided evidence for a greater number of haplotypes in F. sultana (32 vs. 17 for F. sultana and C. mucedo, respectively; $\chi^{2}=4.592, p=0.032$ ). The proportion of unique haplotypes across all populations was not significantly different between the species (23/32 vs. $9 / 17$ for $F$. sultana and C. mucedo, respectively; $Z$-test $=1.325, p=0.183$ ), but a significantly greater proportion of haplotypes was unique to populations of $F$. sultana (15/32 vs. $0 / 17$ for $F$. sultana and C. mucedo, respectively; $Z$-test $=3.388, p<0.001)$.

\section{POTENTIAL FOR PARASITE CO-DISPERSAL}

Waterbirds carrying infections have been particularly implicated in dispersal of disease agents-examples being avian influenza virus (Lebarbenchon et al., 2009), schistosomes causing human cercarial dermatitis (Ebbs et al., 2016) and West Nile virus (Rappole et al., 2000). The potential for zoochory of infected hosts is, however, largely overlooked. Nevertheless, many parasites and pathogens may benefit from and be adapted to such dispersal. Thus, birds may facilitate dispersal of disease agents, although, unlike traditionally recognized disease vectors (e.g., mosquitoes), they do not effect transmission to new hosts. Dispersal of infected statoblasts by waterbirds is a salient example of parasites that hitchhike along with their host.

Myxozoans are endoparasitic cnidarians with complex life cycles, exploiting invertebrate and vertebrate hosts (Okamura et al., 2015). One myxozoan clade-the Malacosporeauses freshwater bryozoans as hosts. The malacosporean Tetracapsuloides bryosalmonae is the causative agent of proliferative kidney disease (PKD) which results in serious economic loss to trout farms and is an emerging disease in wild salmon and trout populations (Okamura et al., 2011; Skovgaard and Buchmann, 2012; Dash and Vasemägi, 2014; Mo and Jørgensen, 2017; Vasemägi et al., 2017). The interactions of $T$. bryosalmonae with its bryozoan host, F. sultana, have thus received considerable investigation. Fredericella sultana statoblasts support cryptic T. bryosalmonae stages and colonies derived from these statoblasts develop infections (Abd-Elfattah et al., 2014, 2017; Fontes et al., 2017) that, in turn, transmit to fish (Abd-Elfattah et al., 2014). Tetracapsuloides bryosalmonae thus achieves vertical transmission (infection of new bryozoan colonies) via infection of statoblasts-a strategy that may introduce the parasite to new populations should infected statoblasts be transported by waterbirds.

Statoblast infection prevalences can be substantial. For example, $39 \%(n=54)$ and $30 \%(n=165)$ of statoblasts collected from $F$. sultana colonies in two river systems were infected with T. bryosalmonae and $95 \%(n=46)$ and $100 \%(n=21)$ of these infected statoblasts successfully hatched (Abd-Elfattah et al., 2014). Infection of statoblasts was similarly inferred for the malacosporean Buddenbrockia allmani, with infections detected in 9 of 10 statoblast-derived colonies of Lophopus crystallinus (Hill and Okamura, 2007). Although there is only a handful of described malacosporeans (Patra et al., 2017), molecular detection of unique isolates in both bryozoans (Hartikainen et al., 2014) and fish (Bartošová-Sojková et al., 2014) suggests that statoblasts may often carry malacosporean infections. Indeed, restriction fragment length polymorphisms and sequencing have revealed infections (including co-infections) of at least five malacosporean species in C. mucedo statoblasts (Ruggeri, Corbishley and Okamura, unpublished data). Survival of infected statoblasts following passage through waterbird digestive tracts has yet to be confirmed, however T. bryosalmonae-infected $F$. sultana statoblasts are viable after passing through carp digestive tracts (Abd-Elfattah et al., 2017).

In view of the evidence for substantial infection prevalences in statoblasts of a range of bryozoan hosts and infected statoblast viability (including following passage through vertebrate digestive tracts) we suggest that parasite co-dispersal may commonly be effected when transported statoblasts colonize new sites. Such co-dispersal requires further study and has been proposed to contribute to the distribution of PKD across Europe and North America (Henderson and Okamura, 2004).

\section{Impacts of Co-dispersal on Populations, Communities, and Biodiversity}

Waterbird-mediated co-dispersal and establishment of parasites and hosts will almost certainly influence community interactions and food webs. Parasite biomass can be considerable (Kuris et al., 2008; Lambden and Johnson, 2013) and parasites contribute substantially to energy transfer and food web structure and stability (e.g., Dunne et al., 2013; MichalskaSmith et al., 2017). Parasites with complex life cycles may exploit hosts at different trophic levels. Parasites can also influence population and community dynamics by altering host behavior, determining host distributions and abundances, and mediating species interactions (e.g., competition, predation) (Hatcher et al., 2012).

Co-dispersal will also influence freshwater biodiversity and evolutionary dynamics. Because aquatic environments are fragmented and heterogeneous in space and time effective dispersal should continuously contribute to metacommunity dynamics. Local adaptation, host-parasite coevolution and disease dynamics will all be influenced by dispersal of parasites and hosts in interconnected networks (Parratt et al., 2016). The consequent mosaic pattern of selection regimes will fundamentally contribute to biodiversity (Thompson, 1999). For example, dispersal may introduce parasites that are particularly virulent if local hosts are not well-adapted to parasite strains (Laine, 2004) or when pathogens shift to new hosts (Longdon et al., 2015). This could result in host population declines that subsequently diminish as reciprocal host-parasite interactions progress through biological arms races. Alternatively, parasites may go extinct if host densities fall below a persistence threshold (Deredec and Courchamp, 2003). 
The consequences of co-dispersal of parasites with different life histories across such landscapes are likely to vary. For example, parasites with complex life cycles or generalists infecting a diversity of hosts may particularly benefit. The former may persist indefinitely in populations of one host even if other hosts are unavailable. The latter may succeed when site conditions are unsuitable for co-dispersing hosts but alternate hosts are available. This scenario highlights potential links between host specificity and virulence evolution (Leggett et al., 2013). Lower virulence could facilitate utilization of dormant host propagules, enabling dispersal. Establishment likelihood would be further increased if the parasite had a broad host range. Co-dispersal could thus drive evolutionary trajectories, promoting the evolution of low virulence strategies in generalist parasites. The potential for parasites to actually manipulate host dispersal is supported by spatial epidemiological modeling (Lion et al., 2006). It would be of interest to explore whether host dispersal could be manipulated when hosts and parasites jointly rely on common dispersal vectors, such as waterbirds, with independent drivers for dispersal.

\section{DIRECTIONS FOR FUTURE STUDIES ON ZOOCHORY OF FRESHWATER INVERTEBRATES}

The sedentary nature of plants has resulted in extensive study of how zoochory of seeds and fruit may explain plant distributions in terrestrial and aquatic environments (e.g., Green et al., 2016; Wenny et al., 2016; Lovas-Kiss et al., 2018b). This perspective has prompted exemplary modeling highlighting how traits such as seed size, survival, and retention time may influence seed dispersal across varying landscapes by local and migratory waterbird movements (Viana et al., 2013; Kleyheeg et al., 2017). Invertebrate dispersal is less well-understood but will critically contribute to patterns of distribution and abundance and organismal interactions. Bryozoans have served as model invertebrate systems for demonstrating zoochory by waterbirds and its corollaries, including codispersal of parasites, and consequences of dispersal variation. This body of work raises further general questions regarding zoochory of freshwater invertebrates including:

\section{REFERENCES}

Abd-Elfattah, A., El-Matbouli, M., and Kumar, G. (2017). Structural integrity and viability of Fredericella sultana statoblasts infected with Tetracapsuloides bryosalmonae (Myxozoa) under diverse treatment conditions. Vet. Res. (2017) 48:19. doi: 10.1186/s13567-017-0427-4

Abd-Elfattah, A., Fontes, I., Kumar, G., Soliman, H., Hartikainen, H., Okamura, B., et al. (2014). Vertical transmission of Tetracapsuloides bryosalmonae (Myxozoa), the causative agent of salmonid proliferative kidney disease. Parasitology 141, 482-490. doi: 10.1017/S0031182013001650

Agami, M., and Waisel, Y. (1986). The role of mallard ducks (Anas platythynchos) in the distribution and germination of seeds of the submerged hydrophyte Najas marina L. Oecologia 68, 473-475. doi: 10.1007/BF01036757
- Are migratory stop-overs zoochory hot spots?

- How important are other agents of zoochory (e.g., insects, mammals, fish, humans)?

- How do rates of zoochory vary over space and time?

- Is endozoochory more important than ectozochory?

- Can zoochory effect spillover of parasites?

- How does zoochory shape the metapopulation dynamics of hosts and parasites?

- How will climate change impact waterbird migrations and hence the distributions of invertebrates and co-dispersing parasites that undergo zoochory?

- Can zoochory select for low virulence strategies in generalist parasites?

- What is the relative importance of other forms of connectivity (e.g., hydrological, anthropogenic) in achieving dispersal?

- How was freshwater biodiversity partitioned before birds evolved?

\section{AUTHOR CONTRIBUTIONS}

BO conceived and wrote the article. $\mathrm{HH}$ was fundamentally involved in many cited studies and contributed to the final development of the article. JT and $\mathrm{HH}$ conducted genetic analyses reported in Figure 1 and Supplementary Tables 1, 2. $\mathrm{HH}$ developed Figure 1.

\section{ACKNOWLEDGMENTS}

Many of the data and insights presented here result from studies funded by the Natural Environment Research Council (grants GR9/828; GR3/8961; GR9/04271; GR3/11068; NER/A/S/1999/00075; NER/B/S/2000/00336; NER/S/A/2004/12399; NE/019227/1; NE/N005902/1), the Biotechnology and Biological Sciences Research Council (BB/F003242/1), the Natural History Museum, London. Comments from two reviewers helped to improve our manuscript.

\section{SUPPLEMENTARY MATERIAL}

The Supplementary Material for this article can be found online at: https://www.frontiersin.org/articles/10.3389/fevo. 2019.00029/full\#supplementary-material

Anderson, H. G. (1959). Food habits of migratory ducks in Illinois. Bull. Ill. Nat. Hist. Surv. 27, 289-344.

Bartošová-Sojková, P., Hrabcová, M., Pecková, H., Patra, S., Kodádková, A., Jurajda, P., et al. (2014). Hidden diversity and evolutionary trends in malacosporean parasites (Cnidaria: Myxozoa) identified using molecular phylogenetics. Int. J. Parasitol. 44, 565-577. doi: 10.1016/j.ijpara.2014.04.005

Bilton, D., Freeland, J. R., and Okamura, B. (2001). Dispersal in freshwater invertebrates. Annu. Rev. Ecol. Syst. 32, 159-181. doi: 10.1146/annurev.ecolsys.32.081501.114016

Brochet,A. L., Gauthier-Clerc, M., Guillemain, M., Fritz, H., Waterkeyn, A., Baltanás, Á., et al. (2010). Field evidence of dispersal of branchiopods, ostracods and bryozoans by teal (Anas crecca) in the Camargue (southern France). Hydrobiologia 637, 255-261. doi: 10.1007/s10750-009-9975-6 
Brown, C. J. D. (1933). A limnological study of certain fresh-water Polyzoa with special reference to their statoblasts. Trans. Amer. Microscop. Soc. 52, 271-316. doi: $10.2307 / 3222415$

Bushnell, J. H. (1973). "The freshwater ectoprocta: a zoogeographical discussion," in Living and Fossil Bryozoa, ed G. P. Larwood (London, UK: Academic Press), 503-521.

Charalambidou, I., Santamaría, L., and Figuerola, J. (2003a). How far can the freshwater bryozoan Cristatella mucedo disperse in duck guts? Arch Hydrobiol. 157, 547-554. doi: 10.1127/0003-9136/2003/0157-0547

Charalambidou, I., Santamaria, L., and Langevoord, O. (2003b). Effect of ingestion by five avian dispersers on the retention time, retrieval and germination of Ruppia maritima seeds. Func. Ecol. 17, 747-753. doi: 10.1111/j.1365-2435.2003.00787.x

Dash, M., and Vasemägi, A. (2014). Proliferative kidney disease (PKD) agent Tetracapsuloides bryosalmonae in brown trout populations in Estonia. Dis. Aquat. Org. 109, 139-148. doi: 10.3354/dao02731

De Meester, L., Gómez, A., Okamura, B., and Schwenk, K. (2002). The Monopolization Hypothesis and the dispersal-gene flow paradox in aquatic organisms. Acta Oecol. 23, 121-135. doi: 10.1016/S1146-609X(02)01145-1

Dendy, J. S. (1963). Observations on bryozoan ecology in farm ponds. Limnol. Oceanogr. 8, 478-482. doi: 10.4319/lo.1963.8.4.0478

Deredec, A., and Courchamp, F. (2003). Extinction thresholds in host-parasite dynamics. Ann. Zool. Fenneci 40, 115-130.

Dunne, J. A., Lafferty, K. D., Dobson, A. P., Hechinger, R. F., Kuris, A. M., et al. (2013). Parasites affect food web structure primarily through increased diversity and complexity. PLoS Biol 11: e1001579. doi: 10.1371/journal.pbio.1001579

Ebbs, E. T., Loker, E. S., Davis, N. E., Flores, V., Veleizan, A., and Brant, S. V. (2016). Schistosomes with wings: how host phylogeny and ecology shape the global distribution of Trichobilharzia querquedulae (Schistosomatida). Int. J. Parasitol. 47, 669-677. doi: 10.1016/j.ijpara.2016.04.009

Excoffier, L., and Lischer, H. E. L. (2010). Arlequin suite ver 3.5, a new series of programs to perform population genetics analyses under Linux and Windows. Mol. Ecol. Resour. 10, 564-567. doi: 10.1111/j.1755-0998.2010.02847.x

Figuerola, J., Green, A. J., Black, K., and Okamura, B. (2004). The influence of gut morphology on passive transport of bryozoans by waterfowl in Doñana (south-west Spain). Can. J. Zool. 82, 835-840. doi: 10.1139/z04-055

Figuerola, J., Green, A. J., and Michot, T. C. (2005). Invertebrate eggs can fly: evidence of waterfowl-mediated gene flow in aquatic invertebrates. Am. Nat. 165, 274-280. doi: 10.1086/427092

Fontes, I., Hartikainen, H., Taylor, N. G. H., and Okamura, B. (2017). Conditional persistence and tolerance characterize endoparasite-colonial host interactions. Parasitology 144, 1052-1063. doi: 10.1017/S0031182017000269

Freeland, J. R., Noble, L. R., and Okamura, B. (2000a). Genetic consequences of the metapopulation biology of a facultatively sexual freshwater invertebrate. J. Evol. Biol. 13, 383-395. doi: 10.1046/j.1420-9101.2000.00192.x

Freeland, J. R., Noble, L. R., and Okamura, B. (2000b). Genetic diversity of North American populations of Cristatella mucedo, inferred from microsatellite and mitochondrial DNA. Mol. Ecol. 9, 1375-1389.

Freeland, J. R., Romualdi, C., and Okamura, B. (2000c). Gene flow and genetic diversity: a comparison of freshwater bryozoan populations in Europe and North America. Heredity 85, 498-508.

Fuentes, C., Sánchez, M. I., Selva, N., and Green, A. J. (2004). Seasonal and age variation in the diet of the Marbled Teal Marmaronetta angustirostris in southern Alicante, eastern Spain. Rev. Ecol. Terre Vie 59, 475-490.

Green, A. J., Frisch, D., Michot, T. C., Allain, L. K., and Barrow, W. C. (2013). Endozoochory of seeds and invertebrates by migratory waterbirds in Oklahoma, USA. Limnetica 32, 39-46. doi: 10.23818/limn.32.05

Green, A. J., Jenkins, K. M., Bell, D., Morris, P. J., and Kingsford, R. T. (2008). The potential role of waterbirds in dispersing invertebrates and plants in arid Australia. Freshw. Biol. 52, 380-292. doi: 10.1111/j.1365-2427.2007.01901.x

Green, A. J., and Sánchez, M. I. (2003). Spatial and temporal variation in the diet of Marbled Teal Marmaronetta angustirostris in the Western Mediterranean. Bird Study 50, 153-160. doi: 10.1080/00063650309461307

Green, A. J., Soons, M., Brochet, A.-L., and Kleyheeg, E. (2016). “Dispersal of plants by waterbirds," in Why Birds Matter. Avian Ecological Function and Ecosystem Services, eds Ç. H. Sekercioglu, D. G. Wenny, C. J. Whelan (Chicago: The University of Chicago Press), 147-195.
Hartikainen, H., Gruhl, A. G., and Okamura, B. (2014). Diversification and repeated morphological transitions in endoparasitic cnidarians (Myxozoa: Malacosporea). Mol. Phylogen. Evol. 76, 261-269. doi: 10.1016/j.ympev.2014.03.010

Hartikainen, H., Waeschenbach, A., Wöss, E., Wood, T., and Okamura, B. (2013). Divergence and species discrimination in freshwater bryozoans (Bryozoa: Phylactolaemata). Zool. J. Linn. Soc. 68, 61-80. doi: 10.1111/zoj.12025

Hatcher, M. J., Dick, J. T. A., and Dunn, A. M. (2012). Diverse effects of parasites in ecosystems: linking interdependent processes. Front. Ecol. Environ. 10, 186-194. doi: 10.1890/110016

Henderson, M. W., and Okamura, B. (2004). The phylogeography of salmonid proliferative kidney disease in Europe and North America. Proc. R. Soc. Ser. B 1549, 1729-1736. doi: 10.1098/rspb.2004.2677

Hengherr, S., and Schill, R. O. (2011). Dormant stages in freshwater bryozoans - an adaptation to transcend environmental constraints. J. Insect Physiol. 57, 595-601. doi: 10.1016/j.jinsphys.2011.03.018

Hill, S. L. L., and Okamura, B. (2007). Endoparasitism in colonial hosts: patterns and processes. Parasitology 134, 841-852. doi: 10.1017/S0031182007002259

Jaganathan, G. K., Yule, K., and Liu, B. (2016). On the evolutionary and ecological value of breaking physical dormancy by endozoochory. Perspectiv. Plant Ecol. 22, 11-22. doi: 10.1016/j.ppees.2016.07.001

Jordano, P. (2017). What is long-distance dispersal? and a taxonomy of dispersal events. J. Ecol. 105, 75-84. doi: 10.1111/1365-2745.12690

Karlson, R. H. (1992). Divergent dispersal strategies in the freshwater bryozoan Plumatella repens: ramet size effects on statoblast numbers. Oecologia 89 , 407-411. doi: 10.1007/BF00317419

Kleyheeg, E., Treep, J., de Jager, M., Nolet, B. A., and Soons, M. B. (2017). Seed dispersal distributions resulting from landscape-dependent daily movement behaviour of a key vector species, Anas platyrhynchos. J. Ecol. 105, 1279-1289. doi: 10.1111/1365-2745.12738

Krementz, D.G., Asante, K., Naylor, L.W., (2011). Spring migration of mallards from Arkansas as determined by satellite telemetry. J. Fish Wildl. Manag. 2, 156-168. doi: 10.3996/042011-JFWM-026

Kuris, A. M., Hechinger, R. F., Shaw, J. C., et al. (2008). Ecosystem energetic implications of parasite and free-living biomass in three estuaries. Nature 454, 515-518. doi: 10.1038/nature06970

Laine, A. L. (2004). Resistance variation within and among host populations in a plant-pathogen metapopulation: implications for regional pathogen dynamics. J. Ecol. 92, 990-1000. doi: 10.1111/j.0022-0477.2004.00925.x

Lambden, J., and Johnson, P. T. J. (2013). Quantifying the biomass of parasites to understand their role in aquatic communities. Ecol. Evol. 3, 2310-2321. doi: $10.1002 /$ ece 3.635

Lebarbenchon, C., Albespy, F., Brochet, A.-L., Grandhomme, V., Renaud, F., Fritz, H., et al. (2009). Spread of avian influenza viruses by Common Teal (Anas crecca) in Europe. PLoS ONE 4:e7289. doi: 10.1371/journal.pone.0007289

Leggett, H. C., Buckling, A., Long, G. H., and Boots, M. (2013). Generalism and the evolution of parasite virulence. Trends Ecol. Evol. 28, 592-596. doi: 10.1016/j.tree.2013.07.002

Lion, S., van Baalen, M., and Wilson, W. G. (2006). The evolution of parasite manipulation of host dispersal. Proc. R. Soc. B 273, 1063-1071. doi: $10.1098 / \mathrm{rspb} .2005 .3412$

Longdon, B., Hadfield, J. D., Day, J. P., Smith, S. C. L., McGonigle, J. E., Cogni, R., et al. (2015). The causes and consequences of changes in virulence following pathogen host shifts. PLoS Pathog 11:e1004728. doi: 10.1371/journal.ppat.1004728

Lovas-Kiss, A., Sánchez, M. I., Molnár, A. V., Valls, L., Armengol, X., MesquitaJoanes, F., et al. (2018a). Crayfish invasion facilitates dispersal of plants and invertebrates by gulls. Freshw. Biol. 63, 392-404. doi: 10.1111/fwb.13080

Lovas-Kiss, Á., Vizi, B., Vincze, O., Molnár, V. A., and Green, A. J. (2018b). Endozoochory of aquatic ferns and angiosperms by mallards in Central Europe. J. Ecol. 106, 1714-1723. doi: 10.1111/1365-2745.12913

Marković, G., Karan-Žnidaršič, T., and Simonivić, P. (2009). Bryozoan species Hyalinella punctata Hancock in the gut content of chub Leuciscus cephalus $\mathrm{L}$. Polish J. Ecol. 57, 201-205.

Massard, J. A., and Geimer, G. (2008). Global diversity of bryozoans (Bryozoa or Ectoprocta) in freshwater: an update. Bull. Soc. Nat. Luxemb. 109, 139-149. doi: 10.1007/978-1-4020-8259-7_11 
Michalska-Smith, M. J., Sander, E. L., Pascual, M., and Allexina, S. (2017). Understanding the role of parasites in food webs using the group model. J. Anim. Ecol. 87, 790-800. doi: 10.1111/1365-2656.12782

Miller, M. R., Takekawa, J. Y., Fleskes, J. P., Orthmeyer, D. L., Casazza, M. L., and Perry, W. M. (2005). Spring migration of Northern Pintails from California's Central Valley wintering area tracked with satellite telemetry: routes, timing, and destinations. Can. J. Zool. 83, 1314-1332. doi: 10.1139/z05-125

Mo, T. A., and Jørgensen, A. (2017). A survey of the distribution of the PKDparasite Tetracapsuloides bryosalmonae (Cnidaria: Myxozoa: Malacosporea) in salmonids in Norwegian rivers - additional information gleaned from formerly collected fish. J. Fish Dis. 40, 621-627. doi: 10.1111/jfd.12542

Mouronval, J.-B., Guillemain, M., Canny, A., and Poirier, F. (2007). Diet of nonbreeding wildfowl Anatidae and Coot Fulica atra on the Perthois gravel pits, northeast France. Wildfowl 57, 68-97.

Okamura, B., and Freeland, J. R. (2002). "Gene flow and the evolutionary ecology of passively dispersing aquatic invertebrates," in Dispersal Ecology, eds. J. M. Bullock, R. E. Kenward, R. S. Hails (Oxford: Blackwell Publishing), 194-216.

Okamura, B., Gruhl, A., and Bartholomew, J. (2015). "An introduction to myxozoan evolution, ecology and development," in Myxozoan Evolution, Ecology and Development, eds. B. Okamura, A. Gruhl, J. Bartholomew (Cham: Springer International Publishing), 1-20.

Okamura, B., Hartikainen, H., Schmidt-Posthaus, H., and Wahli, T. (2011). Proliferative kidney disease as an emerging disease: the importance of life cycle complexity and environmental change. Freshw. Biol. 56, 735-753. doi: 10.1111/j.1365-2427.2010.02465.x

Osburn, R. C. (1921). Bryozoa as food for other animals. Science 5, 451-453. doi: $10.1126 /$ science.53.1376.451

Parratt, S. R., Numminen, E., and Laine, A.-L. (2016). Infectious disease dynamics in heterogeneous landscapes. Annu. Rev. Ecol. Evol. Syst. 47, 283-306. doi: 10.1146/annurev-ecolsys-121415-032321

Patra, S., Hartigan, A., Morris, D., Kodádková, A., and Holzer, A. S. (2017). Description and experimental transmission of Tetracapsuloides vermiformis n. sp. (Cnidaria: Myxozoa) and guidelines for describing malacosporean species including reinstatement of Buddenbrockia bryozoides n. comb. (syn. Tetracapsula bryozoides). Parasitology 144, 497-511. doi: 10.1017/S0031182016001931

Pennycuick, C. J., Åkesson, S., Hedenström, A. (2013). Air speeds of migrating birds observed by ornithodolite and compared with predictions from flight theory. J. R. Soc. Interface 10:20130419

Rappole, J. H., Derrickson, S. R., and Hubálek, Z. (2000). Migratory birds and spread of West Nile virus in the western hemisphere. Emerg. Infect. Dis. 6, 319-328. doi: 10.3201/eid0604.000401

Reynolds, C., and Cumming, G. S. (2015). The role of waterbirds in the dispersal of freshwater cladocera and bryozoa in southern Africa. African Zoology 50, 307-311. doi: 10.1080/15627020.2015.1108164

Sánchez, M. I., Green, A. J., and Dolz, C. (2000). The diets of the White-headed Duck Oxyura leucocephala, Ruddy Duck O. jamaicensis and their hybrids from Spain. Bird Study 47, 275-284. doi: 10.1080/00063650009461187
Skovgaard, A., and Buchmann, K. (2012). Tetracapsuloides bryosalmonae and PKD in juvenile wild salmonids in Denmark. Dis. Aquat. Org. 101, 33-42. doi: 10.3354/dao02502

Swanson, G. A., and Bartonek, J. C. (1970). Bias associated with food analysis in gizzards of blue-winged teal. J. Wildl. Manag. 34, 739-746. doi: $10.2307 / 3799138$

Thompson, J. N. (1999). Specific hypotheses on the geographic mosaic of coevolution. Am. Nat. 153, S1-4. doi: 10.1086/303208

Van Leeuwen, C. H. A., Lovas-Kiss, Á., Ovegård, M., and Green, A. J. (2017). Great cormorants reveal overlooked secondary dispersal of plants and invertebrates by piscivorous waterbirds. Biol. Lett. 13:20170406. doi: 10.1098/rsbl. 2017.0406

Vasemägi, A., Nousiainen, I., Saura, A., Väh,ä, J. P., Valjus, J., and Huusko, A. (2017). First record of proliferative kidney disease agent Tetracapsuloides bryosalmonae in wild brown trout and European grayling in Finland. Dis. Aquat. Org. 125, 73-78. doi: 10.3354/dao03126

Viana, D. S., Santamaria, L., Michot, T. C., and Figuerola, J. (2013). Migratory strategies of waterbirds shape the continental-scale dispersal of aquatic organisms. Ecography 36, 430-438. doi: 10.1111/j.1600-0587.2012.07588.x

Wenny, D. G., Sekercioglu, Ç. H., Cordeiro, N. J., and Rogers, H. S., Kelly, D. (2016). "Seed dispersal by fruit-eating birds," in Why Birds Matter. Avian Ecological Function and Ecosystem Services, eds Ç. H. Sekercioglu, D. G. Wenny, C. J. Whelan (Chicago: The University of Chicago Press), 107-146.

Wood, T. S. (1973). "Colony development in species of Plumatella and Fredericella (Ectoprocta: Phylactolaemata)," in Animal Colonies, Development and Function through Time, eds. R. S. Boardman, A. H. Cheetham, W. A. J. Oliver (Stroudsburg: Dowden, Hutchinson and Ross), 395-432.

Wood, T. S. (2002). "Freshwater bryozoans: a zoogeographical reassessment," in Bryozoan Studies 2001, eds. P. N. W. Jackson, C. J. Buttler, M. E. Spencer Jones (Lisse,: A. A. Balkema Publishers), 339-345.

Wood, T. S., Anurakpongsatorm, P., and Mahujchariyawong, J. (2006). Freshwater bryozoans of Thailand (Ectoprocta and Entoprocta). Nat. Hist. J. Chulalongkorn Univ. 6, 83-119.

Wood, T. S., and Okamura, B. (2005). A New Key to the Freshwater Bryozoans of Britain, Ireland and Continental Europe, with Notes on their Ecology. Ambleside: The Freshwater Biological Association.

Conflict of Interest Statement: The authors declare that the research was conducted in the absence of any commercial or financial relationships that could be construed as a potential conflict of interest.

Copyright (C) 2019 Okamura, Hartikainen and Trew. This is an open-access article distributed under the terms of the Creative Commons Attribution License (CC BY). The use, distribution or reproduction in other forums is permitted, provided the original author(s) and the copyright owner(s) are credited and that the original publication in this journal is cited, in accordance with accepted academic practice. No use, distribution or reproduction is permitted which does not comply with these terms. 